УДК 159

\title{
СОВРЕМЕННАЯ ПСИХОЛОГИЯ
}

Ноздрина Наталья Адександровна

Брянский государственный технический университет, доиент кафедры гуманитарных и соииальных дисииплин, кандидат педагогических наук

Роман Романович Дегтярев

Брянский государственный технический университет, студент кафедры компьютерных технологии и системы

\section{MODERN PSYCHOLOGY}

Natalia Nozdrina Alexandrovna Bryansk state technical University, associate Professor of the Department of Humanities and social Sciences, candidate of pedagogical Sciences

Roman Degtyarev Romanovich Bryansk state technical University, student of the Department of computer technology and systems

Аннотация. В этой статье рассмотрены актуальные вопросы современной психологии, пути ее развития, проблемы и способы их разрешения.

Abstract. This article deals with topical issues of modern psychology, ways of its development, problems and ways to solve them.

Ключевые слова: Психология, современность, общество, развитие.

Keyword: Psychology, modernity, society, development.

Современная психология - это весьма разветвленная наука, имеющая много отраслей. Отрасли психологии представляют собой относительно самостоятельно развивающиеся направления научных психологических исследований.

Психология связана с историческими науками, физиологией и антропологией (человек и общество), медицинскими науками, педагогическими науками.

Важнейшая функция психологии в общей системе научного знания состоит в том, что она, синтезируя в определенном отᄀношении достижения ряда других областей научного знания является, по выражению Б.Ф.Ломова, интегратором всех научных дисциплин, объектом исследования которой является человек. Известный отечественный психолог Б.Г. Ананьев наиболее полно разработал этот вопрос, показав, что психология призвана интегрировать данные о человеке на уровне конкретно-научного знания.

Психология должна вскрыть и физиологические механизмы отражения этих воздействий. Следовательно, психология должна сохранять самую тесную связь с физиологией, и в частности, с физиологией высшей нервной деятельности. Физиология, как известно, занимается механизмами, осуществляющими те или иные функции организма, а физиология высшей нервной деятельности механизмами работы нервной системы, обеспечивающими «уравновешивание» организма со средой. [1]

Проблемы современной психологии:

1. У Психологии, как науки о Душе - полностью материалистичная основа. Это, по сути, делает невозможным определение первопричин и объяснение всех духовных проблем, качеств и явления человеческого существа[3].

2. Отсутствие полноценной рабочей модели Сознания, объясняющей все его явления и процессы: мысли, мышление, образы и воображение, волю, управление собой, тысячи качеств, эмоций и реакций, память[4].

3. Отсутствие полноценной Структуры Личности (модели Личности). Структура личности необходима, чтобы человек мог эффективно развиваться, устранять свои проблемы, избавляться от недостатков и формировать достоинства (раскрывать свой потенциал). Если нет понимания структуры Личности, то и техники развития личности вводятся вслепую, на авось. А если модель Личности понятна, ясны все механизмы, составляющие Личности и связи между ними, тогда можно вводить эффективные техники развития.

4. Отсутствие целостности, логичности и непротиворечивости в знаниях и теориях. Психология сейчас представляет собой множество разрозненных теорий, гипотез, взглядов и подходов, в которых зачастую теория совершенно не стыкуется с практикой[2]. Многие психологи не зная, как помочь человеку убрать ту или иную проблему, обучают клиента маневрировать. приспосабливаться и жить с 
этой проблемой. Как в известном анекдоте, когда после посещения психолога, на вопрос товарища мужчина отвечает, что от энуреза он так и не избавился, но теперь он не комплексует, а гордиться им. От безысходности Психология обучает не решать проблемы, не избавляться от недостатков, а жить с ними.

5. Как следствие всего выше перечисленного это отсутствие адекватных критериев оценки Личности, характеристик человека. Со школы мы знаем традиционные типы темперамента: сангвиник, холерик, флегматик и меланхолик.

\section{Список используемой литературы}

1. Баксанский, О.Е. Современная психология: теоретические подходы и методологические основания. Книга 3: Аффективная сфера личности и психология общения / о.е. Баксанский, В.М. Самойлова. - М.: КД Либроком, 2013. - 368 с.

2. Барышева, А.Д. Этика и психология делового общения (сфера сервиса): Учебное пособие / А.Д. Барышева, Ю.А. Матюхина, Н.Г. Шередер. - М.: Альфа-М, НИЦ ИНФРА-М, 2013. - 256 с.

3. Болотова, А.К. Социальные коммуникации. Психология общения: Учебник и практикум для академического бакалавриата / А.К. Болотова, Ю.М. Жуков, Л.А. Петровская. - Люберцы: Юрайт, 2016. - 327 c.

4. Болотова, А.К. Социальные коммуникации. Психология общения: Учебник и практикум для СПО / А.К. Болотова, Ю.М. Жуков, Л.А. Петровская. Люберцы: Юрайт, 2016. - 327 с. 